\title{
Implementing the Social Functions of Business in the Digital Economy
}

\author{
Natalya Kazarenkova*, Anna Obukhova, and Arkady Maslov \\ Southwest State University, Kursk, Russian Federation
}

\begin{abstract}
Digitalization is an integral part of the development of the economy and society in modern conditions. On the one hand, the introduction of innovative technologies creates new opportunities for business development, on the other hand, dictates new rules and requirements for its organization. At the same time, social and economic development cannot be imagined without taking into account the social dimension of economic growth. Increasing economic indicators of business development in Russia and reducing the growth of social tension is a complex task for the coming years, which determines the relevance of research in the field of implementing social functions of business. This problem became especially important during the coronavirus pandemic, when the need to protect individual social groups of citizens and provide various types of social services through remote access was manifested. The transformation of the service sector under the influence of the digitalization process poses the business community with the task of accessibility of socially significant products and services in $24 / 7$ mode. It should be noted that business socialization is carried out at the intersection of entrepreneurship and charity and is embodied in various business models. The article addresses the problems of developing modern forms of implementing the social functions of business in the context of the digital transformation of the economy and society. One of the tools to solve the problem of implementing the social functions of the business in the environment is the mechanism for developing and implementing social business projects, taking into account their effectiveness and social significance.
\end{abstract}

\section{Introduction}

The social component of the parameters for achieving economic growth is now important for ensuring a high quality of life for the country's population, which determines its position in terms of the level of socio-economic development in the world ranking. The degree of development of the social sphere is determined by the existence and state of a social service system designed to meet the needs of socially vulnerable sectors of society (pensioners, disabled people, children, single mothers, the poor, large families). Given the paid nature of most social services, it is necessary to implement the social functions of business through the charitable activities of entrepreneurs and the provision of social services free of charge.

\footnotetext{
${ }^{*}$ Corresponding author: nfedorovich@yandex.ru
} 
One of the modern forms of implementing the social functions of business is social entrepreneurship. However, in the Russian business development practice, this direction is quite new, and the provision of social services is carried out within the framework of classic business models, taking into account the possibility of their digital transformation $[1,2]$. In this regard, the problem of implementing the social functions of business, including in the digital environment, as a means of achieving competitiveness and creating public goods, is relevant for all social service subjects. At the same time, the development of social entrepreneurship in the Russian economy is possible on the basis of a reasonable choice of the most effective business model, including in terms of its social significance.

The implementation of the social functions of the business is possible as part of the development and implementation of social entrepreneurship projects that ensure the achievement of a synergistic effect of the combination of business and charity. The need for social responsibility of business is connected with the importance of reducing the level of social tension as a factor of economic and social destabilization. The social orientation of business allows strengthening social protection of citizens, reducing the degree of social stratification of society, improving the quality of life and, in general, ensuring socioeconomic development $[3,4,5]$. It should be noted that the effectiveness of economic growth currently depends directly on the achievement of a high level of national well-being and in meeting the needs of citizens. That is why the formation of the institutional foundations of social entrepreneurship and the stimulation of its development contributes to the implementation of the social functions of business through the implementation of socially significant projects.

The novelty of the institute of social entrepreneurship for the Russian economy is reflected in the lack of a sufficient empirical base for conducting serious research in the field of assessing its development prospects. In this regard, theoretical and methodological studies of the problems of implementing the social functions of business are formed under the influence of the works of foreign economists, the extrapolation of which into the practice of developing social entrepreneurship allows us to assess its potential in the conditions of the Russian economy. The general theoretical and methodological foundations of research on the development of entrepreneurship at various stages of its formation and formation are considered in the works of scientists such as T. Hobbes, P. Drucker, R. Cantillon, P. Krugman, A. Marshall, J. S. Mill, J.B. Say, A. Smith, M. Friedman, J. Schumpeter.

At the same time, it should be noted that the phenomenon of social entrepreneurship itself is quite innovative, which determines the lack of elaboration of all aspects of its development. In this regard, the relevance of the study is confirmed by the need to summarize and develop theoretical, methodological and organizational provisions for the study of social entrepreneurship in order to increase the effectiveness of the practical implementation of social business projects.

\section{Background}

Social responsibility of business has been an important issue since the birth of entrepreneurial activity. Concern for public welfare, although it does not directly affect the level of economic development, is a significant component of ensuring the quality of life of the population. The development and implementation of social business projects allows you to most fully and effectively solve the problems of socio-economic development of the country. And one of the tools for implementing this task is the institute of social entrepreneurship.

The repetition of the world financial and economic crises, the acceleration of the pace of changing economic cycles indicate the low efficiency of achieving the country's socio- 
economic development based exclusively on market or administrative methods of management. Under these circumstances, the combination of social and economic methods of development is the best solution. The transition to a socio-market model of development is possible subject to rethinking the role of the State and business in ensuring the functioning of the economic system $[6,7]$.

Public-private partnership provides an opportunity for the most effective solution of socially significant issues and tasks based on the development and implementation of social business projects. At the same time, social partnership, as a way of interaction between the state, business and society, is most often implemented through the creation of non-profit organizations. It should be noted that any business project can bring public benefits and contribute to the realization of social functions, however, a full and comprehensive solution to problems of a social nature is characteristic only of business models within the framework of social entrepreneurship. Comparative analysis of models of implementation of social functions of business is presented in Table 1.

Table 1. Typology of social entrepreneurship models

\begin{tabular}{|l|l|l|l|}
\hline $\begin{array}{c}\text { Model } \\
\text { Characteristics }\end{array}$ & \multicolumn{1}{|c|}{ Charity model } & \multicolumn{1}{|c|}{ Hybrid model } & \multicolumn{1}{|c|}{$\begin{array}{c}\text { Commercial } \\
\text { model }\end{array}$} \\
\hline Motivation & good will & $\begin{array}{l}\text { a combination of social and } \\
\text { economic motives }\end{array}$ & personal benefits \\
\hline Practices & $\begin{array}{l}\text { defined by the } \\
\text { mission }\end{array}$ & $\begin{array}{l}\text { a combination of mission and } \\
\text { market conditions is defined }\end{array}$ & $\begin{array}{l}\text { determined by } \\
\text { market } \\
\text { conditions }\end{array}$ \\
\hline Purposes & creating social value & $\begin{array}{l}\text { building social and economic } \\
\text { value creating } \\
\text { economic value }\end{array}$ \\
\hline $\begin{array}{l}\text { Profit } \\
\text { Assignment }\end{array}$ & $\begin{array}{l}\text { aimed directly at the } \\
\text { implementation of the } \\
\text { mission (determined } \\
\text { by the law or policy } \\
\text { of the organization) }\end{array}$ & $\begin{array}{l}\text { is reinvested in mission } \\
\text { implementation, or in operating } \\
\text { expenses and/or held for } \\
\text { business expansion and } \\
\text { development (may be partially } \\
\text { reallocated among participants) }\end{array}$ & $\begin{array}{l}\text { distributed } \\
\text { among } \\
\text { shareholders and } \\
\text { owners }\end{array}$ \\
\hline
\end{tabular}

The constant changes taking place in the modern economic system, including under the influence of digitalization processes, contribute to changes in the forms and directions of the provision of social services, as well as in the parameters of assessing the quality of social services. Including there is a change and modification of subjects of public relations in the implementation of social business projects. This situation is caused, on the one hand, by the active development of public-private partnership mechanisms, on the other, by the "digital transformation" of public administration and the main sectors of the social sphere.

Digitalization of the public sphere of activity is based on various digital platforms and methods of communication, which reduces the space and time frame of interaction between the recipient of social services and the social organization. Nevertheless, despite the increase in the level of technological effectiveness and quality of life of the population through the introduction of digital innovations, at the same time, the risks of responsibility of social project performers, as well as the requirements of social clients for the quality of social service, are growing [8].

Despite the impact of the negative factors of the digital transformation of the social services sector, the need to digitalize the social services system is obvious. The backlog in technological change will negatively affect not only the quality and accessibility of social services, but also the pace of socio-economic development of the country as a whole. In this regard, the creation of conditions for the functioning of the institution of social 
entrepreneurship is an important state task, the solution of which depends on the possibility of implementing social business projects on digital platforms [9]. The creation of such platforms for the promotion of social services in Russia is carried out at the state level using budget financing, and social entrepreneurs, among other things, have the opportunity to place their proposals. On the basis of such a partnership, mutually beneficial tasks are being solved: on the one hand, business gets access to digital technologies, the introduction of which requires significant (and most often unsustainable for social entrepreneurs) costs, on the other hand, the state solves the problem of social security for citizens, partially relieving the burden from public organizations [10]. As a rule, the creation of non-profit organizations, as subjects of social entrepreneurship, is currently aimed at solving problems and serving socially unprotected segments of the population. The structure of such organizations by target potential customer categories is shown in Figure 1.

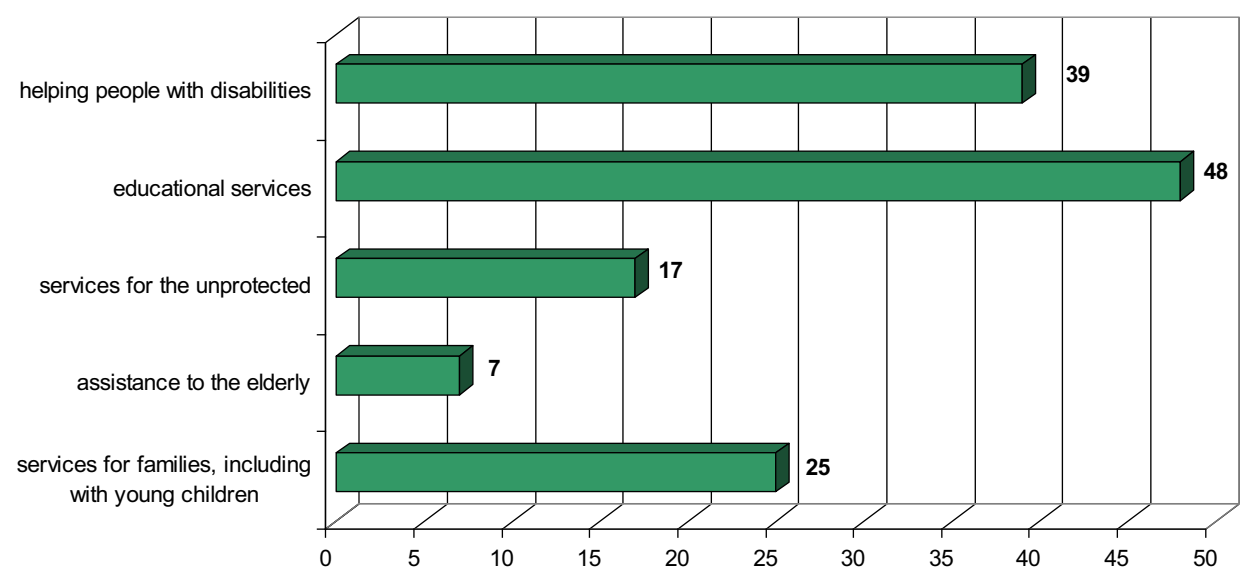

Fig. 1. Number of social enterprises in Russia ranked by target groups

Leveraging public finance enables the use of digital platforms in social services. An example of such a digital transformation is the Portal of Social Services, as a single point of entry of citizens to receive social services provided to the population by providers (social entrepreneurs). With the help of this digital platform, citizens can order specific social services from non-profit organizations, and the authorities of the constituent entities of the Russian Federation can monitor the quality of the provision of social services and allocate budget allocations to providers of such services. The stages of operation of the digital business model with the involvement of non-profit organizations to expand the social functions of the business are shown in Figure 2.

The full digital transformation of social business and the introduction of digital business models is based on the development and implementation of qualitatively new approaches to the implementation of activities and allows to reduce transaction costs [11]. The result of the implementation of digital business models in the field of social services is a synergy of innovative technologies and traditional service channels, which generates qualitatively new digital services and changes the entire process of providing social services. Parameters of business model selection and possibilities of digital transformation by types of social services are presented in Table 2 . 


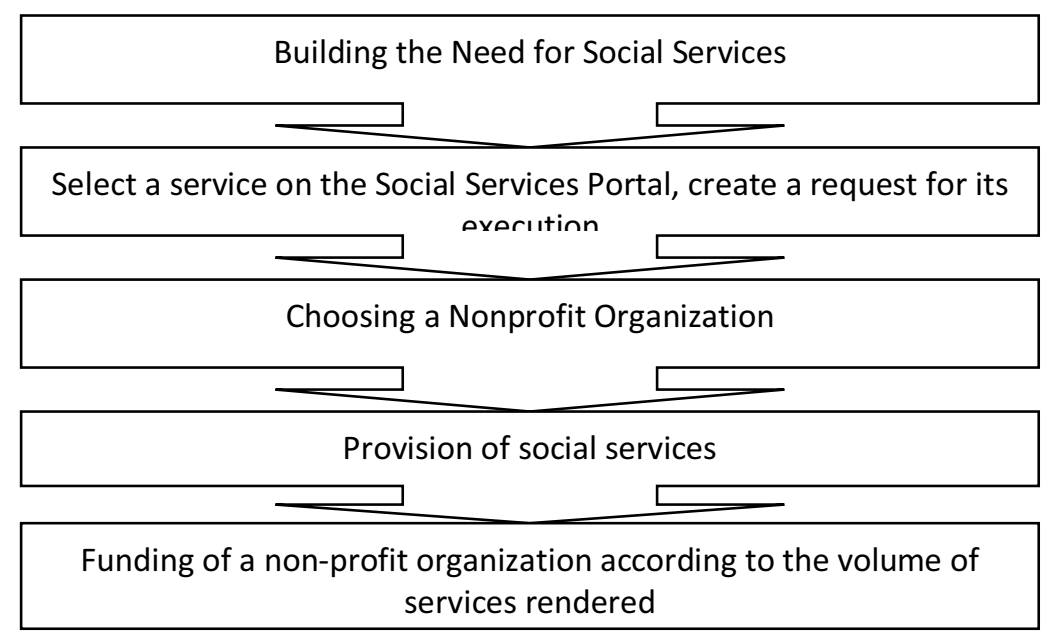

Fig. 2. Implementing social business functions through the digital platform Social Services Portal

Table 2. Business model type selection parameters by social service type

\begin{tabular}{|c|c|c|c|}
\hline $\begin{array}{l}\text { Types of social } \\
\text { services }\end{array}$ & $\begin{array}{c}\text { Traditional Business } \\
\text { Model }\end{array}$ & $\begin{array}{c}\text { Digitalization of social } \\
\text { services }\end{array}$ & $\begin{array}{c}\text { Digital Business } \\
\text { Model }\end{array}$ \\
\hline Medical services & $\begin{array}{l}\text { Initial medical } \\
\text { referral, emergency } \\
\text { cases and surgeries, } \\
\text { receiving } \\
\text { prescriptions }\end{array}$ & $\begin{array}{l}\text { Telemedicine, e-sick } \\
\text { list, mobile applications }\end{array}$ & Unable to use \\
\hline $\begin{array}{l}\text { Educational } \\
\text { services }\end{array}$ & \begin{tabular}{l}
\multicolumn{3}{l}{ A classic approach to } \\
education with the \\
inclusion \\
interactive \\
technologies
\end{tabular} & $\begin{array}{l}\text { Partial use of digital } \\
\text { technologies (electronic } \\
\text { diary, student ratings) }\end{array}$ & $\begin{array}{l}\text { Remote education } \\
\text { format based on } \\
\text { digital education } \\
\text { platforms and cloud } \\
\text { technologies }\end{array}$ \\
\hline Cultural services & $\begin{array}{l}\text { Visiting theatres, } \\
\text { museums, } \\
\text { exhibitions }\end{array}$ & Online sale of tickets & $\begin{array}{l}\text { Virtual tours and } \\
\text { excursions }\end{array}$ \\
\hline Transport services & $\begin{array}{l}\text { Use of airport ticket } \\
\text { offices, train stations }\end{array}$ & $\begin{array}{l}\text { Online sale of tickets, } \\
\text { travel cards }\end{array}$ & Unable to use \\
\hline $\begin{array}{l}\text { Physical education } \\
\text { and sports services }\end{array}$ & $\begin{array}{ll}\text { Classes } & \text { in gyms, } \\
\text { sports } & \text { complexes, } \\
\text { stadiums } & \\
\end{array}$ & $\begin{array}{l}\text { Video tutorials, } \\
\text { videoconferencing } \\
\text { sessions }\end{array}$ & Unable to use \\
\hline
\end{tabular}

Indicators of socio-economic efficiency can take into account the results of the project, the degree of its impact on the quality of life of the population and on the development of the regional economy as a whole. At the same time, both the entrepreneur's direct results and costs for the social business project and the accompanying additional results characterizing efficiency in terms of environmental, social and other non-economic parameters are subject to assessment. However, identifying, calculating and evaluating the cost-effectiveness expressed in monetary terms is, in most cases, difficult. An integrated approach to assessing the effectiveness of a social business project allows translating both social and economic indicators of its implementation into quantitative parameters (Figure 3). 


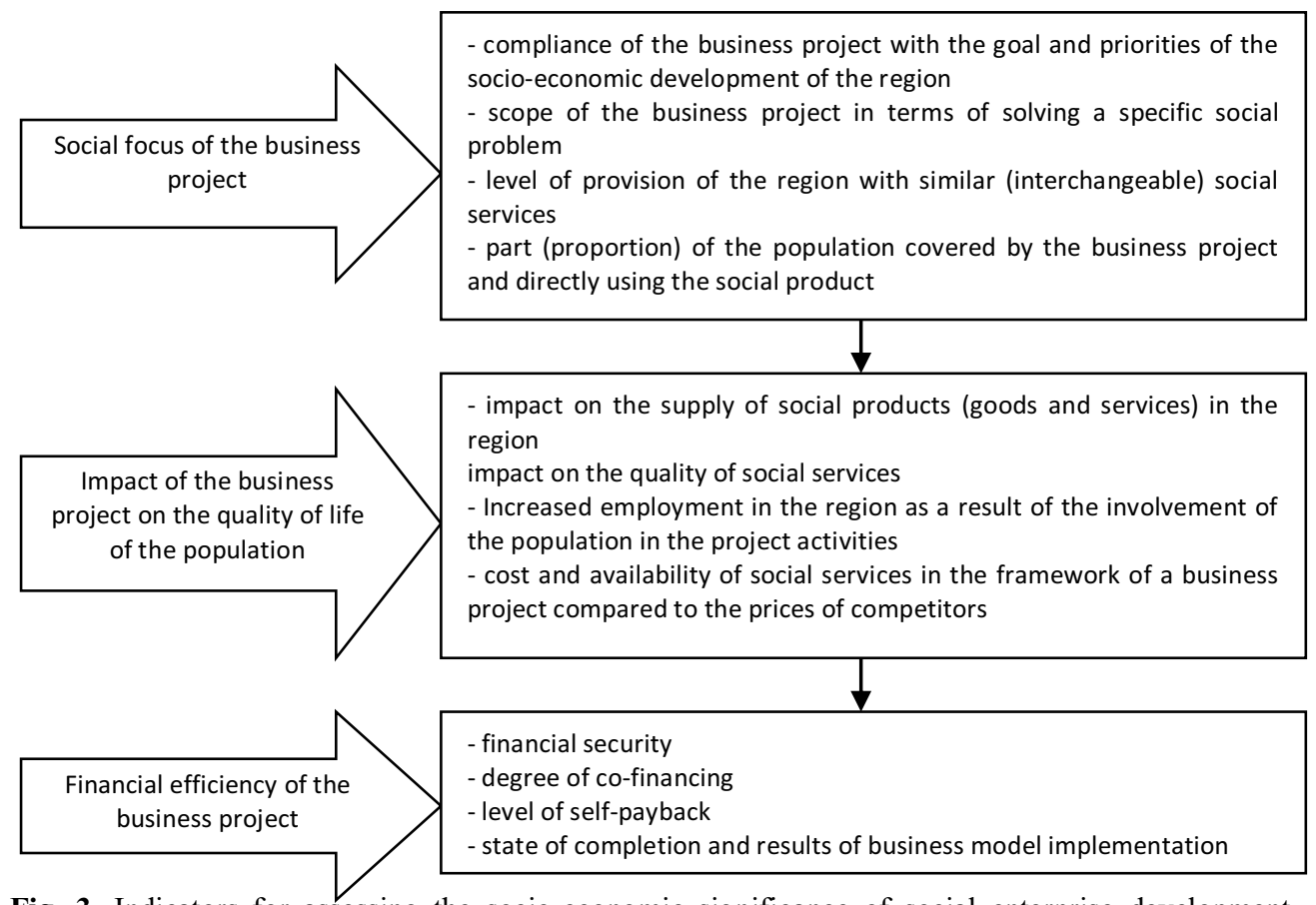

Fig. 3. Indicators for assessing the socio-economic significance of social enterprise development projects

Each indicator corresponds to a certain scale of values and a number of conditions, as well as the specific weight of a specific indicator in each group, which is calculated in order of priority. The total weight of the indicators in each of the groups should be equal to one: the result is determined by summing the indicators in each of the groups, which in turn are determined by multiplying the specific weight of the indicator by the corresponding value in the groups presented. Then the aggregate coefficient of the significance of social projects looks like the weighted average of the indicators of the social significance of the project according to the formula:

$$
\mathrm{K}_{\mathrm{SS}}=\sum_{i=1}^{N} S S_{i} \times S W I_{i},
$$

where $\mathrm{SSi}$ - value of the i-th indicator of social significance in points;

SWIi - specific weight of the i-th indicator;

$\mathrm{N}$ - number of indicators.

To date, there is not a single replicated, innovative and globally recognized social project or enterprise in Russia. Corporate social responsibility of commercial companies remains more popular in our country. Firstly, it is the fulfillment by companies of the social obligations prescribed by law and the willingness to bear the corresponding mandatory costs. Secondly, corporate social responsibility is the company's willingness to voluntarily incur non-binding social spending is needed beyond the limits established by tax, labor, environmental and other laws, based not on the requirements of laws, but on its own, moral and ethical reasons. In this regard, it is necessary to intensify the development of social entrepreneurship on the basis of the economic mechanism for the implementation of social business projects, taking into account their social significance (figure 4). 


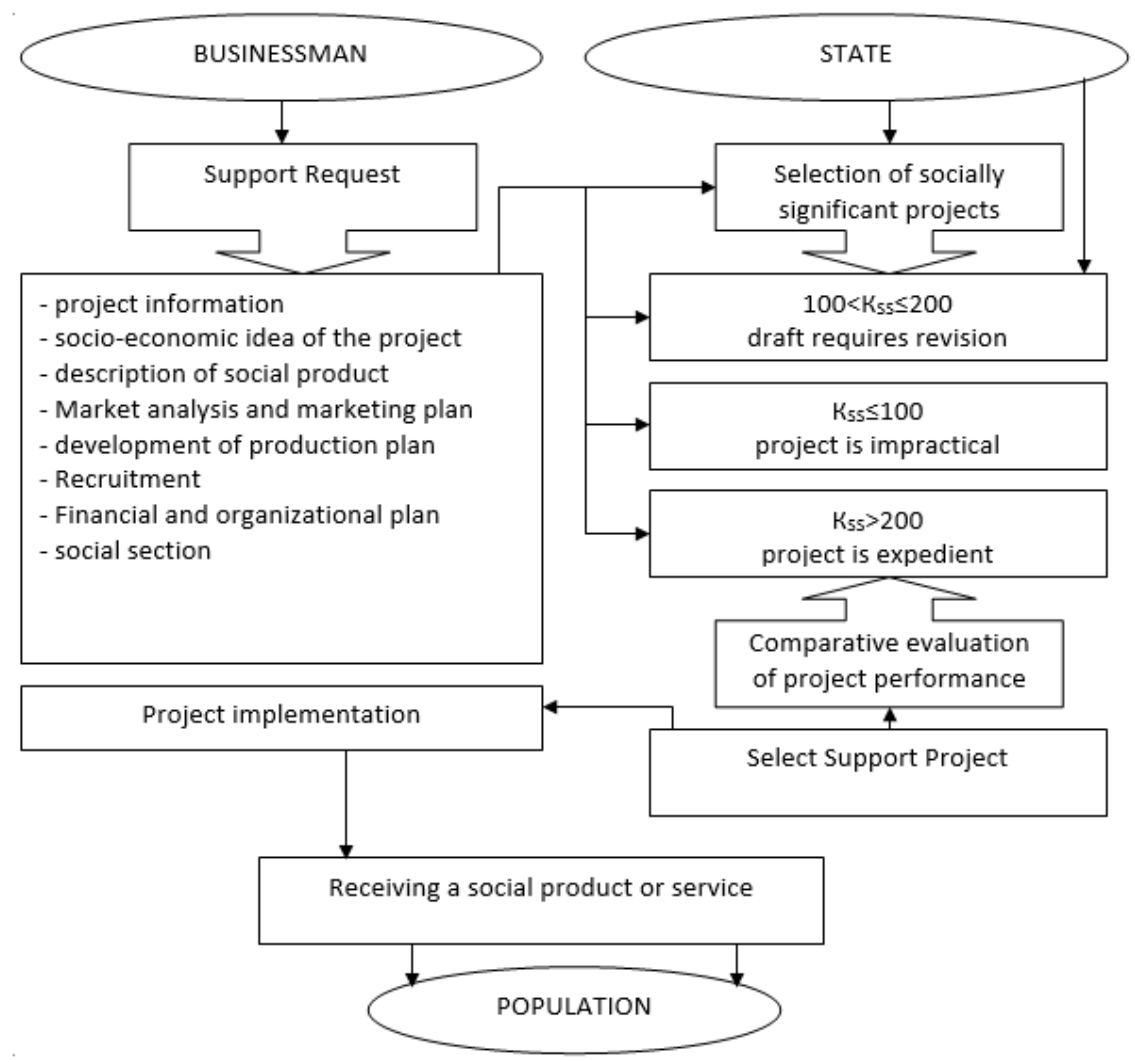

Fig. 4. Economic mechanism for the implementation of a business project in the field of social entrepreneurship, taking into account the assessment of its social significance

In general, it can be concluded that the digitalization of social services has a positive impact at all levels of the socio-economic system - from an individual consumer to the country as a whole. The introduction of innovative digital business models in the field of social services is justified in cases where the quality and degree of satisfaction of the end user does not decrease. As practice shows, the process of digitalization of social services carries a set of positive effects for various subjects (Table 3).

Table 3. Effectiveness of the digital transformation of social services

A new source of GDP growth

EFFECTIVENESS FOR THE COUNTRY AS A WHOLE

Positive net effect on number of jobs

Improve resource utilization

\begin{tabular}{|c|c|c|}
\hline $\begin{array}{c}\text { EFFECTIVENESS FOR THE } \\
\text { STATE }\end{array}$ & $\begin{array}{c}\text { EFFICIENCY FOR SOCIAL } \\
\text { BUSINESS }\end{array}$ & $\begin{array}{c}\text { EFFICIENCY FOR } \\
\text { CONSUMERS }\end{array}$ \\
\hline
\end{tabular}

Improving the effectiveness of social services

Reducing fraud and abuse in obtaining public services

Improving interaction with citizens, providing feedback

Identifying and analyzing social trends with big data
Expanding the range of social services in one business project

Improving the efficiency of internal processes

Staff development

Improving the simplicity and transparency of interaction with the state and consumers of social services
Choice of the best conditions for social services and social service requests

Ability to use previously unavailable services (with remote access)

Facilitating access to social and public services through digital platforms 
Implementation of a digital format for the provision of social services or digitalization of part of the process of their provision will allow social entrepreneurs to achieve competitive advantages, which they can use at the very beginning of their journey to to move faster from ideas to concepts, and from them to profit, with minimal risk and cost, getting closer to customers and building relationships between the system and partners, and gaining flexibility in digital shocks and maximizing the synergistic effect of digital transformation through platformization.

\section{Conclusions}

Thus, the proposed approach to comparative evaluation of social business projects, which is based on the interests of the parties involved in the process of implementing the project in the field of social entrepreneurship, integrally reflects the ability of the entrepreneur to transform the diverse opportunities identified in certain conditions into economic benefits in order to maximize the satisfaction of the mutually agreed interests of social service subjects. The direct result of activities within the framework of the project in the field of social entrepreneurship in the event of a successful outcome of the evaluation of the effectiveness of the project according to the proposed methodology contributes to the dissemination of positive experience and the formation of long-term consequences, supported by state support as an incentive and motivation for the implementation of social functions of the business.

\section{References}

1. N.I. Zvereva, N.Yu. Surova, N.V. Kulikova, S.V. Golubev, E.N. Feoktistova Social Entrepreneurship, 544 (2017).

2. N.V. Studenikin Influence of digital technologies on social services: world experience and prospects in Russia, Izvestia of Tula State University. Humanities, 1, 32-36 (2018).

3. Peter F. Drucker Innovation and Entrepreneurship: Practice and Principles, 368 (2015).

4. I.V. Malofeev Social services in the system of social services of the population, 176 (2018).

5. N.V. Romanova Digitalization of services in the social sphere: problems and prospects, Bulletin of UGNTU. Science, education, economics. Series: Economics, 1, 58-65 (2020).

6. T. Kolmykova, E. Merzlyakova, B. Preobrazhensky, N. Serebryakova Problems of investment support for innovative development, Proceedings of the 33rd International Business Information Management Association Conference, IBIMA 2019: Education Excellence and Innovation Management through Vision 2020, 2199-2204 (2019).

7. T. Kolmykova, E. Merzlyakova, B. Preobrazhensky, N. Serebryakova Theoretical approaches to the study of socially-oriented infrastructure of the region, Proceedings of the 33rd International Business Information Management Association Conference, IBIMA 2019: Education Excellence and Innovation Management through Vision 2020. 33, Education Excellence and Innovation Management through Vision 2020, 10061011 (2019).

8. S.K. Alter Social Enterprise Typology, 124 (2007).

9. T.S. Kolmykova, S.G. Emelyanov, E.A. Merzlyakova Research of innovative potential of the region, Journal of Applied Engineering Science, 3, 276-279 (2017).

10. A.A. Moskovskaya, I.V. Soboleva Social entrepreneurship in the system of social policy: world experience and prospects of Russia, Problems of forecasting, 6, 103-111 (2016).

11. N.I. Zvereva Creation of a successful social, 155 (2015). 